\title{
Purification and Characterization of Extracellular, Polyextremophilic $\alpha$ - amylase Obtained from Halophilic Engyodontium album
}

\author{
Imran Ali 1,2*, Ali Akbar 3, Muhammad Anwar 2, Benjawan Yanwisetpakdee 1, Sehanat Prasongsuk 1, \\ Pongtharin Lotrakul 1, Hunsa Punnapayak 1,** \\ ${ }^{1}$ Plant Biomass Utilization Research Unit, Department of Botany, Faculty of Science, Chulalongkorn University, Bangkok, \\ 10330, THAILAND \\ ${ }^{2}$ Institute of Biochemistry, University of Balochistan, Quetta, 87300, PAKISTAN \\ ${ }^{3}$ Food Engineering and Bioprocess Technology, School of Environment, Resources and Development, Asian Institute of \\ Technology, Klong Luang, Pathumthani, 12120, THAILAND \\ *Corresponding Author: Imran Ali, Plant Biomass Utilization Research Unit, Department of Botany, Faculty of Science, \\ Chulalongkorn University, Bangkok, 10330, THAILAND. Tel: +66-2218-5477, Fax: +66-2252-8979, E-mail: imranal- \\ isheik@gmail.com \\ ${ }^{* *}$ Co-Corresponding Author: Hunsa Punnapayak, Plant Biomass Utilization Research Unit, Department of Botany, Faculty of \\ Science, Chulalongkorn University, Bangkok, 10330, Thailand, E-mail: phunsa@chula.ac.th
}

Received: February 14, 2014; Revised: October 20, 2014; Accepted: November 01, 2014

Background: $\alpha$-Amylases (EC 3.2.1.1) are covering approximately $25 \%$ of total enzyme market and are frequently used in food, pharmaceutical and detergent industries.

Objectives: The first ever detailed characterization of amylase from any halophilic Engyodontium album is presented.

Materials and Methods: An extracellular $\alpha$-amylase was studied from halophilic E. album TISTR 3645. The enzyme was extracted and purified by column chromatography. SDS-PAGE was performed to find the molecular weight of the enzyme. The effects of $\mathrm{pH}$, temperature and salinity on the isolated enzyme were determined. The effects of various additives on enzyme were studied.

Results: The molecular weight of the amylase was $50 \mathrm{kDa}$. The enzyme specific activity was $132.17 \mathrm{U}_{\mathrm{mg}} \mathrm{m}^{-1}$ with $V_{\max }$ and $K_{\mathrm{m}}$ values of $15.36 \mathrm{U} \cdot \mathrm{mg}^{-1}$ and $6.28 \mathrm{mg}^{-\mathrm{ml}^{-1}}$, respectively. The optimum enzyme activities were found at $\mathrm{pH} 9.0,60^{\circ} \mathrm{C}$ and $30 \%(\mathrm{w} / \mathrm{v}) \mathrm{NaCl} . \mathrm{BaCl}_{2}, \mathrm{CaCl}_{2}, \mathrm{HgCl}_{2}$ and $\mathrm{MgCl}_{2}$ improved amylase activity. $\beta$-mercaptoethanol, EDTA, $\mathrm{FeCl}_{2}$ and $\mathrm{ZnCl}_{2}$ decreased enzyme activity.

Conclusions: Polyextremophilic characteristics of $\alpha$-amylase from halophilic E. album TISTR 3645 were revealed during the characterization studies, demonstrating promising features, making it a useful candidate for various industries.

Keywords: $\alpha$-amylase; Engyodontium album; Extremozyme; Halophilic fungi

\section{Background}

Fungi capable of growing in salinities above $1.7 \mathrm{M}$ in vivo and $3 \mathrm{M}$ of salt in vitro are classified as halophilic fungi $(1,2)$.

Halophiles and their metabolites have tremendous applications such as bioactive compounds, biosurfactants, biocompatible solutes and food additives (3-5). Moreover, halophiles produce potential hydrolytic enzymes that are capable of working in many industrial processes (6). Currently, halophilic bacteria and their metabolites monopolized the related industries (7). On the contrary, little data has been augmented for halophilic fungi (2), despite the fact that more often fungal species are better sources of metabolites and halophilic enzymes (8). $\alpha$-Amylases are enzymes used in varieties of industries such as food, feed, pharma- ceuticals and detergents, taking up $25 \%$ of the enzyme market (9-11).

\section{Objectives}

Here, a native halophilic fungus, E. album TISTR was isolated and characterized both morphologically and via molecular analysis. The fungal $\alpha$-amylase properties were analyzed following enzyme purification. To the best of our knowledge this is the first report of amylase from E. album.

\section{Materials and Methods}

\subsection{Fungal Isolation}

E. album TISTR 3645 was isolated from extreme hypersaline conditions at man-made solar saltern, 
located in Ban Laem district of Phetchaburi province, Thailand (12). In growth characterization studies the fungus was found to be a halophile (13). The strain was later deposited to Thailand Institute of Scientific and Technological Research (TISTR) culture collection.

\subsection{Enzyme Screening}

The presence of $\alpha$-amylase from $E$. album TISTR 3645 was performed by plate screening method according to Ali et al. (2). E. album was grown on PDA plates, supplemented with $1 \%(\mathrm{w} / \mathrm{v})$ starch.

\subsection{Growth Conditions for Enzyme PSroduction}

The media for amylase production was made according to Hernandez et al. (14), containing 8.0 g. $1^{1-}$ $\mathrm{CaCO}_{3}, 0.15$ g.1 ${ }^{1-} \mathrm{FeSO}_{4} .7 \mathrm{H}_{2} \mathrm{O}, 3.5$ g.1- $\mathrm{KH}_{2} \mathrm{PO}_{4}$, 0.10 g. $1^{1-} \mathrm{MgSO}_{4} .7 \mathrm{H}_{2} \mathrm{O}, 3.0$ g. $1^{1-}$ mycological peptone, 6.6 g.1 ${ }^{1-}\left(\mathrm{NH}_{4}\right)_{2} \mathrm{SO}_{4}$ and $10 \mathrm{~g} .1^{1-}$ starch .

\subsection{Amylase Purification}

Amylase was isolated according to Chakraborty et al. and Hmidet et al. $(15,16)$. The culture broth was centrifuged for $10 \mathrm{~min}$ at $13,000 \times \mathrm{g}$ in $4^{\circ} \mathrm{C}$. Enzyme was precipitated by $90 \%$ saturated $\left(\mathrm{NH}_{4}\right)_{2} \mathrm{SO}_{4}$. The mixture was left overnight at $4^{\circ} \mathrm{C}$. The precipitate was centrifuged for $30 \mathrm{~min}$ at $12,000 \times \mathrm{g}$ and dissolved in $100 \mathrm{mM}$ Tris- $\mathrm{HCl}$ buffer ( $\mathrm{pH}$ 8.0). The enzyme was dialyzed against same buffer for $48 \mathrm{~h}$. For further purification Sephadex G-100 column $(2.6 \mathrm{~cm}-150 \mathrm{~cm})$ pre-equilibrated with $25 \mathrm{mM}$ Tris- $\mathrm{HCl}$ buffer ( $\mathrm{pH} 8.0$, containing $0.5 \% \mathrm{v} / \mathrm{v}$ Triton $\mathrm{X}-100$ ). Enzyme fractions of $5 \mathrm{ml}$ were eluted with the same buffer at a flow rate of $30 \mathrm{ml}^{-\mathrm{h}^{-1}}$.

Sodium dodecyl sulphate polyacrylamide gel electrophoresis (SDS-PAGE) was performed according to Hmidet et al. (2008) to determine molecular weight and enzyme purity in a $15 \%$ resolving gel. For the determination of molecular weight the molecular marker kit (Bio-Rad) was used as reference.

\subsection{Amylase Assay}

Dinitrosalicylic acid (DNS) method for the measurement of reducing sugar was used for the determination of amylase activity (17). Amylase $(0.1 \mathrm{ml})$ was added to $0.5 \mathrm{ml}$ of $0.1 \mathrm{M}$ phosphate buffer supplemented with $1 \%(\mathrm{w} / \mathrm{v})$ soluble starch and incubated for 10 $\min$ at $40^{\circ} \mathrm{C}$. The reaction was stopped by the addition of $3 \mathrm{ml}$ of 3, 5-dinitrosalicylic acid and heated for 5 min in boiling water. The reaction mixture brought up to $10.6 \mathrm{ml}$ using $\mathrm{dH}_{2} \mathrm{O}$ and the absorbance was record- ed at $540 \mathrm{~nm}$. One unit of enzyme activity (U) was defined as the amount of enzyme that produced $1 \mu \mathrm{mol}$ of glucose in $1 \mathrm{~min}$.

\subsection{Protein Estimation}

The amount of protein was estimated by the Lowry method (18). Bovine serum albumin (BSA) was used as the standard.

\subsection{Characterization of Amylase}

The enzyme was characterized by studying the effects of $\mathrm{pH}$, temperature and salinity. The results are explained by percentage relative activity. The effect of $\mathrm{pH}$ was determined by incubating the sample mixture in $\mathrm{pH}$ 5-12 at constant temperature. For acidic range of $\mathrm{pH}, 0.1 \mathrm{M}$ acetate buffer was used, while for alkaline and neutral ranges of $\mathrm{pH}, 0.1 \mathrm{M}$ phosphate buffer was used. The effect of temperature was determined by incubating the sample mixtures in $30-90^{\circ} \mathrm{C}$ at constant $\mathrm{pH}$. The effect of salinity was estimated by supplementing the sample mixture with $0-40 \% \mathrm{NaCl}$ concentration $(\mathrm{w} / \mathrm{v})$, at constant $\mathrm{pH}$ and temperature.

The effect of various additives on enzyme activity was determined by using $2 \mathrm{mM} \mathrm{HgCl}, \mathrm{BaCl}_{2}, \mathrm{ZnCl}_{2}$, $\mathrm{FeCl}_{2}, \mathrm{MgCl}_{2}, \mathrm{CaCl}_{2}$, ethylene diamine tetra acetic acid (EDTA) and $\beta$-mercaptoethanol.

\subsection{Determination of Kinetic Parameters}

The Kinetic studies were performed by incubating the amylase with different concentrations of soluble starch. Optimum conditions were used in kinetic studies. The values of $V_{\max }$ and $K_{\mathrm{m}}$ were obtained from the Lineweaver-Burk plot.

\section{Results}

\subsection{Purification of Amylase}

The E. album was found to have amylase by plate screening method. The crude enzyme was extracted from the media and applied to column chromatography. The fractions showing the highest amylase activity was selected for the determination of molecular weight and purity of enzyme. The enzyme was found to have a single band with relative molecular mass of $50 \mathrm{kDa}$ (Figure 1). The specific activity of amylase was $132.17{\mathrm{U} . \mathrm{mg}^{-1}}^{-1}$.

\subsection{Characterization of Amylase}

The percentage relative activity of enzyme in different $\mathrm{pH}$ showed that enzyme was able to work better in neutral and alkaline $\mathrm{pH}$ ranges (Figure 2). A steady 


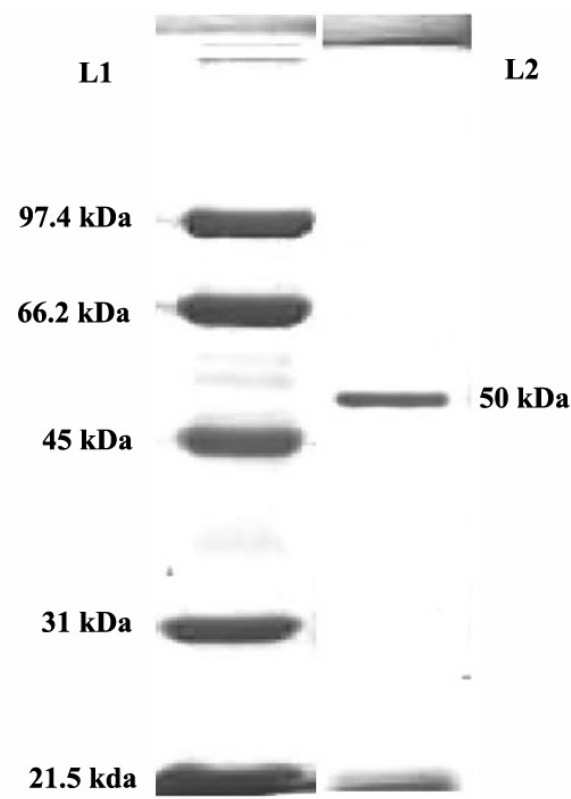

Figure 1. SDS-PAGE analysis of the purified $\alpha$-amylase from $E$. album TISTR 3645. L1: represents lane 1, which is the molecular mass ladder. L2: represents lane 2, which is the purified $\alpha$-amylase lane, showing single band at approximately $50 \mathrm{kDa}$

increase in enzyme activity was observed from $\mathrm{pH} 5$ 9. The highest enzyme activity was observed at $\mathrm{pH} 9.0$. A sharp decline in enzyme activity was noted at $\mathrm{pH}$ values greater than 9.0 .

Isolated amylase worked better in moderate to high temperature values (Figure 3). A sharp incline in enzyme activity was observed from $40-60^{\circ} \mathrm{C}$. The enzyme optimum temperature was $60^{\circ} \mathrm{C}$ and in temperatures above the activity declined. The enzyme was able to retain almost $60-85 \%$ of its relative activity at higher temperatures of 80 and $90^{\circ} \mathrm{C}$, where most of enzymes become denatured.

Increase in salinity by $0-30 \%(\mathrm{w} / \mathrm{v})$ of $\mathrm{NaCl}$ increased the activity of the enzyme (Figure 4). The highest enzyme activity was found at $30 \% \mathrm{NaCl}$. Although the enzyme activity was decreased in greater salt concentrations, it still kept about $85 \%$ of its relative activity at $40 \%$ of salt concentration, which is over the saturation point of salt solution.

$\mathrm{BaCl}_{2}, \mathrm{CaCl}_{2}, \mathrm{HgCl}_{2}$ and $\mathrm{MgCl}_{2}$ increased the amylase activity, but not greater than $110 \%$ (Table 1). In contrast, $\beta$-mercaptoethanol, EDTA, $\mathrm{FeCl}_{2}$ and $\mathrm{ZnCl}_{2}$ decreased the enzyme activity. The greatest inhibition occurred in the presence of $\mathrm{ZnCl}_{2}$. The decrease in enzyme activity was never less than $60 \%$ by the addition of any inhibitor.

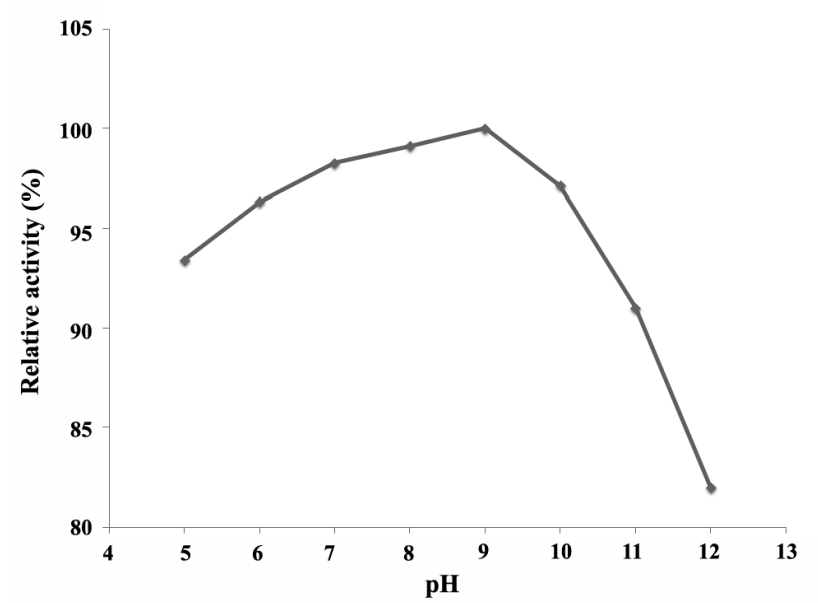

Figure 2. Effect of $\mathrm{pH}$ on the purified $\alpha$-amylase activity from E. album TISTR 3645 at constant temperature. The results are presented in percentage relative activity

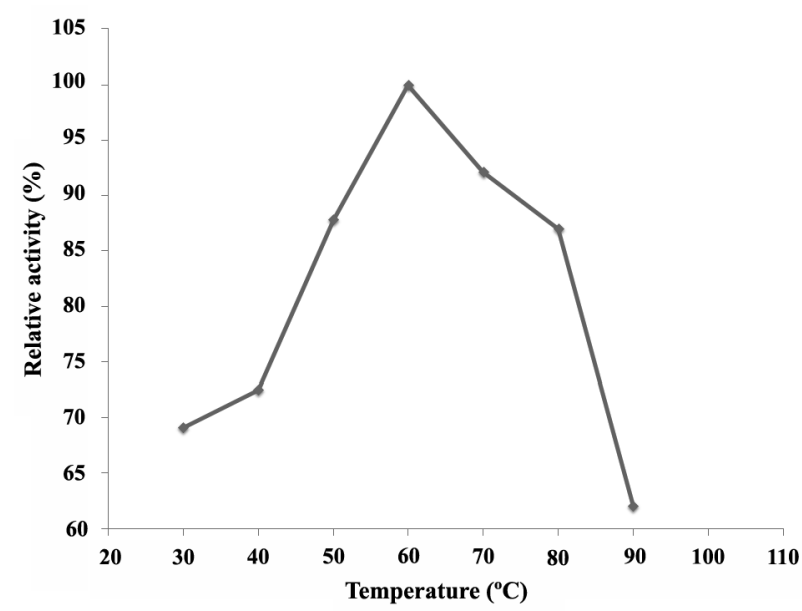

Figure 3. Effect of temperature on the purified $\alpha$-amylase activity from $E$. album TISTR 3645 at constant $\mathrm{pH}$. The results are presented in percentage relative activity

\section{Discussion}

Researchers are constantly working on finding suitable fungal strains for amylase production (19). Amylases from fungi have mostly been reported from mesophilic fungi (20), especially from Aspergillus and Penicillium genus (21). Even though, the enzymes from fungi are preferred to be used in industries (8), the enzymes from halophilic fungi have been neglected as compared to the bacterial counterparts (2). Except few preliminary screenings no reports of purification and detailed characterization of $\alpha$-amy- 


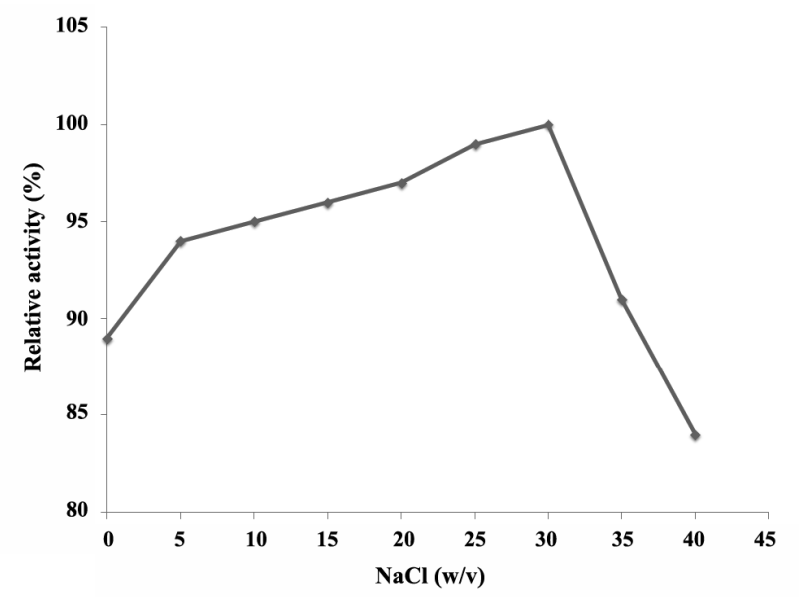

Figure 4. Effect of $\mathrm{NaCl}$ concentrations (\% w/v) on the purified $\alpha$-amylase activity from $E$. album TISTR 3645 at constant $\mathrm{pH}$ and temperature. The results are presented in percentage relative activity

lases from halophilic fungi exists. E. album has not been much reported for its potential of extracellular enzymes except few reports of proteases $(22,23)$.

Presence of single band of approximately $50 \mathrm{kDa}$ was found during the purification of amylase (Figure 1), which shows that there is no need for any further purification of enzyme. The specific activity of the enzyme is found in a good range (15). The value of $K_{\mathrm{m}}$ has been found to fall in the most reported ranges of 0.35-11.66 mg.ml-1 for amylases (24).

The $\mathrm{pH}$ characterization study shows the typical behavior of halophilic fungi adaptation to its habitat. The hypersaline habitats are mostly found to have neutral to alkaline range of $\mathrm{pH}$ (4). In our earlier report (12), we found that most of the fungi in growth characterization were able to grow best from neutral to alkaline $\mathrm{pH}$ as well. The $\mathrm{pH}$ values of 9 and 10 are mostly considered enough to designate the enzyme as alkalophilic $(25,26)$. Alkalophilic amylases are mostly applied in the detergent industries (9).

Most of the enzymes are unable to perform the catalytic activity at high temperature values of $50-60^{\circ} \mathrm{C}$ (27). The $\alpha$-amylase in this study has been found to have optimum activity at $60^{\circ} \mathrm{C}$ and retain more than $85 \%$ of its activity at high temperatures of $70-80^{\circ} \mathrm{C}$, which are considered as thermophilic range for enzymes $(28,29)$. This character shows that, it has the capability to withstand high temperature processes that are mostly carried out in starch industries (27).

The E. album in the previous study has been found
Table 1. Effect of various additives on the purified $\alpha$-amylase from $E$. album TISTR 3645 . The results are presented in percentage relative activity

\begin{tabular}{lc}
\hline Additives (2 mM) & Relative activity (\%) \\
\hline None & 100 \\
$\mathrm{BaCl}_{2}$ & $100.23 \pm 1.5$ \\
$\mathrm{CaCl}_{2}$ & $110.48 \pm 0.4$ \\
$\mathrm{FeCl}_{2}$ & $63.11 \pm 0.01$ \\
$\mathrm{HgCl}_{2}$ & $103.04 \pm 1.5$ \\
$\mathrm{MgCl}_{2}$ & $101.02 \pm 1.5$ \\
$\mathrm{ZnCl}$ & $71.34 \pm 1.5$ \\
$\beta-\mathrm{mercaptoethanol}_{\text {EDTA }}$ & $76.48 \pm 0.2$ \\
\hline
\end{tabular}

to withstand the salinity ranges of $0-20 \%$ of $\mathrm{NaCl}$ $(\mathrm{w} / \mathrm{v})(13)$. This extreme characteristic requires modification in the working capabilities of the metabolites in the halophiles (1). The catalytic ability of $\alpha$-amylase in this study at high salt concentrations makes this enzyme novel. This capability is much greater than the previously reported bacterial and Archeal amylases (6, $9,30)$. Ability of this amylase to work at extreme salt concentrations makes them the best available candidate to work for bioremediation processes, particularly, saline waste management $(31,32)$. Similarly the limiting water resources and availability of hard water for domestic uses in current climate change, requires the additive amylases for detergents to work better in low water activity for minimizing the consumption of water, as well as to make more cleaning effects in the presence of high salt concentrations (33). Halophilic enzymes are also reported to work better than normal enzymes in biofuel productions (34).

The increase of activity due to the addition of almost half of the additives makes this amylase to work better in the presence of several additives. The inhibition of amylase from few additives has not been found more than $40 \%$ which shows the resistance of inhibition from the studied amylase.

Halophilic microbes are frequently been reported to provide polyextremophilic amylases $(6,8)$. Mostly they have found to be haloalkalophilic having thermotolerant characteristic (35). Polyextremophilic enzymes are better candidates than monoextremophilic enzymes since most industrial processes require enzymes to withstand multiple harsh conditions (36), such as: $\mathrm{pH}$, temperature and salinity. 


\section{Conclusions}

$\alpha$-amylase from E. album TISTR 3645 found to be more extremophilic in properties than the fungus itself. This finding may suggest that other primary and secondary metabolites from halophilic fungi demonstrate polyextremophilic behavior. Accordingly, it would be fair to state that looking into halophilic fungi may promise greater advantages over using bacterial counterparts in related industries. The polyextremophilic behavior shown by $\alpha$-amylase obtained from $E$. album, makes this enzyme a suitable choice to be used in extreme conditions of industries; particularly as additive in detergents as well as for the treatment of extreme saline waste water.

\section{Acknowledgements}

We would like to thank all, who helped us during the process of this study and manuscript preparation.

\section{Authors' contributions}

IA conducted the research, AA helped in enzyme purification, MA provided consultation, BY helped in characterization studies, SP and PL provided consultations and lab facilities and HP supervised the research.

\section{Funding/Support}

The Research Grant Funds have been provided by agreement on Post-Doctoral Research Grant Allocation from the Ratchadaphisek Somphot Fund. This research has also been supported by National Research University Project, Office of Higher Education Commission (WCU-038-EN-57).

\section{References}

1. Gunde-Cimerman N, Frisvad JC, Zalar P, Plemenitaš A. Halotolerant and halophilic fungi. In: Deshmukh SK, Rai MK (eds), Biodiversity of Fungi-Their Role in Human Life. Oxford \& IBH Publishing Co. Pvt. Ltd., New Delhi, 2005; pp. 69-128.doi:http://dx.doi.org/10.1007/1-4020-3633-7_26

2. Ali I, Siwarungson N, Punnapayak H, Lotrakul P, Prasongsuk S, Bankeeree W, Rakshit SK. Screening of potential biotechnological applications from obligate halophilic fungi, isolated from a man-made solar saltern located in Phetchaburi province, Thailand. Pak J Bot. 2013; 46:983-988.

3. Das Sarma S, DasSarma P. Halophiles, Encyclopedia of Life Sciences. Wiley, London 2002. doi: http://dx.doi.org/10.1038/npg.els.0000394

4. Gostinčar C, Lenassi M, Gunde-Cimerman N, Plemenitaš A. Fungal adaptation to extremely high salt concentrations. $A d v$ in $A p p l$ Microbiol. 2011;77:71-96.doi:http://dx.doi.org/10.1016/b978-0-12387044-5.00003-0

5. Oren A. Industrial and environmental applications of halophilic microorganisms. Environ Technol. 2010;31:825-834. doi: http://dx.doi.org/10.1080/09593330903370026
6. Moshfegh M, Shahverdi AR, Zarrini G, Faramarzi MA. Biochemical characterization of an extracellular polyextremophilic alpha-amylase from the halophilic archaeon Halorubrum xinjiangense. Extremophiles. 2013;17:67787.doi:http://dx.doi.org/10.1007/s00792-013-0551-7

7. Dalboge H. Expression cloning of fungal enzyme genes: A novel approach for efficient isolation of enzyme genes of industrial relevance. FEMS Microbiol Rev. 1997;21:2942.doi:http://dx.doi.org/10.1111/j.1574-6976.1997.tb00343.x

8. Niknejad F, Moshfegh M, Najafzadeh MJ, Houbraken J, Rezaei S, Zarrini G, Faramarzi MA, Nafissi-Varcheh N. Halotolerant ability and $\alpha$-amylase activity of some saltwater fungal isolates. Iran J Pharm Res. 2013;12:113-9.

9. Kiran KK, Chandra TS. Production of surfactant and detergent-stable, halophilic, and alkalitolerant alpha amylase by a moderately halophilic Bacillus sp. strain TSCVKK. Appl Microbiol Biotechnol. 2008;77:1023-1031. doi: http://dx.doi.org/10.1007/s00253-007-1250-z

10. Liu XD, Xu Y. A novel raw starch digesting $\alpha$-amylase from a newly isolated Bacillus sp. Yx-1: purification and characterization. Bioresour Technol. 2008;99:4315-4320. doi: http://dx.doi.org/10.1016/j.biortech.2007.08.040

11. Shafiei M, Ziaee A, Amoozegar MA. Purification and biochemical characterization of a novel SDS and surfactant stable, raw starch digesting, and halophilic bacterium Nesterenkonia sp. strain F. Process Biochem. 2010;45:694699.doi:http://dx.doi.org/10.1016/j.procbio.2010.01.003

12. Ali I, Kanhayuwa L, Rachdawong S, Rakshit SK. Identification, phylogenetic analysis and characterization of obligate halophilic fungi isolated from a man-made solar saltern in Phetchaburi province, Thailand. Ann Microbiol. 2013;63:887-895.doi:http://dx.doi.org/10.1007/s13213-0120540-6

13. Ali I, Rakshit SK, Siwarungson N, Punnapayak H, Lotrakul P, Prasongsuk S, Akbar A, Rehman Z. Identification and phylogenetic analysis of halophilic fungus isolated from a manmade solar saltern in Thailand. LUJST. 2013;2:47-52.

14. Hernandez MS, Rodriguez MR, Guerra NP, Roses RP. Amylase production by Aspergillus niger in submerged cultivation on two wasters from food industries. J Food Eng. 2006;73:93100.doi:http://dx.doi.org/10.1016/j.jfoodeng.2005.01.009

15. Chakraborty S, Khopade A, Kokare C, Mahadik K, Chopade B. Isolation and characterization of novel $\alpha$-amylase from marine Streptomyces sp. D1. J Mol Catal B Enzyme. 2009;58:17-23.doi:http://dx.doi.org/10.1016/j.molcatb.2008.10.011

16. Hmidet N, Bayoudh A, Berrin JG, Kanoun S, Juge N, Nasri M. Purification and biochemical characterization of a novel $\alpha$-amylase from Bacillus licheniformis NH1: cloning, nucleotide sequence and expression of amy $\mathrm{N}$ gene in Escherichia coli. Process Biochem. 2008;43:499510.doi:http://dx.doi.org/10.1016/j.procbio.2008.01.017

17. Miller GL. Use of dinitrosalicylic acid reagent for determination of reducing sugar. Anal Chem. 1959;31:426428.doi:http://dx.doi.org/10.1021/ac60147a030

18. Lowry OH, Rosebrough NJ, Farr AL, Randall RJ. Protein measurement with the Folin-Phenol reagents. J Biol Chem. 1951;193:265-275. 
19. De Souza PM, Magalhues PO. Application of microbial $\alpha$ amylase in industry-a review. Brazilian $J$ Microbiol. 2010;41:850-861.

20. Gupta R, Gigras P, Mohapatra H, Goswami VK, Chauhan B. Microbial $\alpha$-amylases: a biotechnological perspective. Process Biochem. 2003;38:15991616.doi:http://dx.doi.org/10.1016/s0032-9592(03)00053-0

21. Kathiresan K, Manivannan S. $\alpha$-Amylase production by Penicillium fellutanum isolated from mangrove rhizosphere soil. Afr J Biotechnol. 2006;5:829-832.

22. Chellappan S, Jasmin C, Basheer SM, Elyas KK, Bhat S, Chandrasekaran M. Production, purification and partial characterization of a novel protease from marine Engyodontium album BTMFS10 under solid state fermentation. Process Biochem. 2006;41:956961.doi:http://dx.doi.org/10.1016/j.procbio.2005.10.017

23. Chellappan S, Jasmin C, Basheer SM, Kishore A, Elyas KK, Bhat SG, Chandrasekaran M. Characterization of an extracellular alkaline serine protease from marine Engyodontium album BTMFS10. J Ind Microbiol Biotechnol. 2011;38:743752.doi:http://dx.doi.org/10.1007/s10295-010-0914-3

24. Najafi MF, Kembhavi A. One step purification and characterization of an extracellular a-amylase from marine Vibrio $s p$. Enzyme Microb Technol. 2005;36:535539.doi:http://dx.doi.org/10.1016/j.enzmictec.2004.11.014

25. Prakash B, Vidyasagar M, Madhukumar MS, Muralikrishna G, Sreeramulu K. Production, purification, and characterization of two extremely halotolerant, thermostable, and alkalistable $\alpha$-amylases from Chromohalobacter sp. TVSP 101. Process Biochem. 2009;44:210215.doi:http://dx.doi.org/10.1016/j.procbio.2008.10.013

26. Varalakshmi KN, Kumudini BS, Nandini BN, Solomon J, Suhas R, Mahesh B, Kavitha AP. Production and characterization of $\alpha$-amylase from Aspergillus niger JGI 24 isolated in Bangalore. Pol J Microbiol. 2009;58:29-36.

27. Prakash O, Jaiswal N. $\alpha$-amylase: An Ideal Representative of Thermostable Enzymes. Appl Biochem Biotechnol. 2010;160:2401-2414.doi:http://dx.doi.org/10.1007/s12010009-8735-4

28. Fincan SA, Enez B. Production, purification, and characterization of thermostable $\alpha$-amylase from thermophilic Geobacillus stearothermophilus. Starch/Stärke. 2014;66:182189.doi:http://dx.doi.org/10.1002/star.201200279

29. Gomes I, Gomes J, Stenier W. Highly thermostable amylase and pullulanase of the extreme thermophilic eubacterium Rhodothermus marinus: production and partial characterization. Bioresource Technol. 2003;90:207214.doi:http://dx.doi.org/10.1016/s0960-8524(03)00110-x

30. Shafiei M, Ziaee A, Amoozegar MA. Purification and characterization of a halophilic $\alpha$-amylase with increased activity in the presence of organic solvents from the moderately halophilic Nesterenkonia sp. strain F. Extremophiles. 2012;16:627-635.doi:http://dx.doi.org/10.1007/s00792-0120462-z

31. Chung J, Shin S, Oh J. Characterization of a microbial community capable of reducing perchlorate and nitrate in high salinity. Biotechnol Lett. 2009;31:959-966.doi:http://dx.doi.org/10.1007/s10529-0099960-1
32. Ali I, Akbar A, Yanwisetpakdee B, Prasongsuk S, Lotrakul P, Punnapayak H. Purification, characterization and potential of saline waste water remediation of a polyextremophilic $\alpha$-amylase from an obligate halophilic Aspergillus gracilis. Biomed Res. Int. 2014.doi:http://dx.doi.org/ 10.1155/2014/106937.

33. Park JS, Song JH, Yeon KH, Moon SH. Removal of hardness ions from tap water using electromembrane processes. Desalination. 2007;202:18.doi:http://dx.doi.org/10.1016/j.desal.2005.12.031

34. Zhang TS, Datta J, Eichler N, Ivanova SD, Axen CA, Kerfeld F, Chen N, Krypidis P, Hugenholtz J, Cheng KL, Sale B, Simmons A, Rubbin E. Identification of a haloalkaliphilic and thermostable cellulase with improved ionic liquid tolerance. Green Chem. 2011;13:20832090.doi:http://dx.doi.org/10.1039/c1gc15193b

35. Setati ME. Diversity and industrial potential of hydrolase-producing halophilic/halotolerant eubacteria. Afr J Biotechnol. 2010;9:1555-1560.

36. Asad W, Asif M, Rasool SA. Extracellular enzyme production by indigenous thermophilic bacteria: partial purification and characterization of $\alpha$-amylase by Bacillus sp. wa21. Pak J Bot. 2011;43:1045-1052. 